\title{
Periprosthetic Osteolysis and its Association with RANKL Expression
}

\author{
D. VEIGL ${ }^{1}$, J. NIEDERLOVÁ², O. KRYŠTƯFKOVÁ ${ }^{2}$ \\ ${ }^{1}$ Department of Orthopedics, First Faculty of Medicine, Charles University, Prague and ${ }^{2}$ Institute \\ of Rheumatology, Prague, Czech Republic
}

Received April 5, 2006

Accepted August 8, 2006

On-line available August 22, 2006

\begin{abstract}
Summary
Extensive osteolysis adjacent to orthopedic implants is often associated with wear particles of prosthetic material. The activation of the RANKL/RANK/OPG system is considered to be a likely cause of periprosthetic osteolysis leading to implant failure. The aim of this study was to examine the possible correlation between the clinical extent of osteolysis, the number of wear particles and expression of the osteoclastic mediator RANKL (receptor activator of nuclear factor kappa B ligand) in the tissues around aseptically loosened cemented and non-cemented total hip replacements. Periprosthetic tissues were harvested from 59 patients undergoing revision of hip replacement for aseptic loosening. We observed RANKL-positive cells in 23 of our 59 patients, their presence was noted predominantly in tissues with a loosened cemented endoprosthesis. We have found that RANKL is present only in tissues with a large amount of wear debris and predominantly in cases involving loosened cemented implants.
\end{abstract}

Key words

RANK • RANKL • Leptin • Periprosthetic osteolysis

\section{Introduction}

In the past decade major advances in our understanding of bone metabolism physiology have been made. Particularly, a large number of important regulators of the formation of osteoclasts and bone resorption have been identified. Recently, newly identified molecules such as the receptor activator of nuclear factor kappa B (RANK), the RANK ligand (RANKL), and osteoprotegerin (OPG), also known as osteoclastogenesis inhibitory factor, have been shown to play crucial roles in the differentiation of osteoclasts (Yasuda et al. 1998).

The bone resorption is influenced by hormones (thyrocalcitonin, parathyroid hormone, calcitriol), pro-inflammatory cytokines (IL-1, IL-6, TNF-alpha, IL-17), prostaglandins and glucocorticoids. Leptin, which previously was not thought to influence bone metabolism, has recently been added to this list (Haluzík et al. 1999, 2001, Maruna et al. 2001, Křížová et al. 2003). Most of these factors do not act on the differentiation and activation of osteoclasts directly, but by means of molecules controlling bone formation and resorption RANKL and OPG. Animal studies using gene deletion and overexpression have shown that RANKL is essential for the formation of osteoclasts. RANK is expressed on the surface of myeloid progenitor cells, preosteoclasts, mature osteoclasts, and $\mathrm{T}$ and $\mathrm{B}$ lymphocytes. Osteoclast 
progenitors of the monocyte-macrophage lineage with the surface receptor RANK recognize the RANK ligand in osteoblasts/stromal cells through cell-to-cell interaction, and then differentiate into osteoclasts. A decoy receptor for RANKL - osteoprotegerin (OPG) - is a soluble tumor-necrosis factor (TNF)-like receptor molecule, which inhibits osteoclast formation by competing for the binding of RANKL to its receptor on preosteoclasts (Lacey et al. 1998). According to recent data, the production of OPG is influenced by leptin which increases the level of OPG mRNA in peripheral monocytes, and therefore down-regulates osteoclast formation by influencing the RANK/RANKL/OPG system.

Numerous studies illustrate the clinical success of total hip arthroplasty. The surgery is considered to be routine, with a minimal rate of early complications and offering dramatic pain relief and functional improvement (Landor et al. 1994). However, it remains a solution for a damaged hip joint only for a limited time, since up to $30 \%$ of patients experience a loosening of the implant within 10-14 years of the initial surgery. Aseptic loosening has been recognized as the main reason for revisions.

Wear between the primary bearing surfaces is considered to be the most important source of prosthetic particles. Depending on the type of implant, such wear particles can be polyethylene, metal, polymethylmetacrylate or ceramic (Landor et al. 1993, 1997, Sosna et al. 1996). Wear particles are not inert for the organism, and it has been shown that particles with a size of about $1 \mu \mathrm{m}$ evoke the most intense tissue reaction (Schmalzried et al. 1992, Šlouf et al. 2004). More than $90 \%$ of wear particles are smaller than $1 \mu \mathrm{m}$ in diameter, with a mean size of $0.5 \mu \mathrm{m}$. Particles of all the biomaterials presently in use can provoke an adverse biological reaction in the periprosthetic tissues, involving the formation of osteolytic foreign body granulomas (Chun et al. 1999). At present, monocyte/macrophages are believed to play a key role in this process. Mononuclear phagocyte cells attempt to eliminate large numbers of foreign particles by phagocytosis. Small particles are easily phagocytozed, but they cannot be digested. The inability to degrade the engulfed particles leads to an increased production of numerous mediators and cytokines by stimulated macrophages, especially IL-1 and TNF alpha. The result of this reaction provoked by the particles is the excessive accumulation of bone resorbing factors and osteolysis, leading to a failure of the endoprosthesis.
The activation of the RANKL/RANK/OPG system is considered to be the most probable cause of periprosthetic osteolysis leading to implant failure. However, the precise pathophysiological mechanism and the exact moment when the balance between the resorption and production of bone shifts towards resorption are not clear. The purpose of our study was to investigate this issue. Specifically, we sought to examine the possible correlation between the clinical extent of osteolysis, the number of wear particles and the expression of the osteoclastic mediator RANKL in the tissue around aseptically loosened total hip replacements.

\section{Materials and Methods}

Periprosthetic tissues were harvested from 59 patients undergoing hip replacement revision for aseptic loosening of the implant. The prostheses were all radiographically and clinically loosened at the time of surgery when subjected to manual manipulation. An infection of the hip endoprosthesis was excluded in all cases by clinical examination, laboratory investigation (FW, CRP) and negative aerobic and anaerobic cultures (Jahoda et al. 2000, 2003a,b, 2004, Vavř́k et al. 2000, Landor et al. 2005). The age of patients at the time of revision ranged from 52 to 84 years, and the time between implantation and surgical revision ranged from 35 to 260 months. The diagnosis before the original surgery was osteoarthritis in 51 cases and rheumatoid arthritis in 8 cases.

In our group of 59 patients, 14 cases involved a loosening of both prosthetic components, 27 cases a loosening of the acetabular component and 18 cases a loosening of the femoral component. Within the 41 total cases with a loosened acetabular component, 23 cases involved a Poldi polyethylene cup and 18 cases a Walter non-cemented cup. Of the 32 total cases with a loosened femoral component, 11 cases involved a cemented Poldi stem, 14 cases a CF30 cemented stem and 7 cases a Walter non-cemented stem (Table 1).

Tissue specimens were harvested from a representative and readily accessible portion of the bonecement interface, eventually bone-implant interface, using curettes during revision surgery. Tissue specimens were approximately $5 \mathrm{~mm}$ in diameter. In osteolytic cases, the specimens were always harvested from an area of bone destruction. All specimens were investigated by the first author.

Immediately after removal, tissue specimens 
Table 1. The occurrence of RANKL-positive tissues according to the component loosened and the type of implant.

\begin{tabular}{llcc}
\hline Component & \multicolumn{1}{c}{ Type of implant (material) } & $\begin{array}{c}\text { Implanted } \\
\text { endoprosthesis }\end{array}$ & $\begin{array}{c}\text { Number of RANKL } \\
\text { positive tissues }\end{array}$ \\
\hline Acetabularcemented & Poldi (polyethylen cemented cup) & 23 & 11 \\
Acetabular Non-cemented & Walter (sandblasted titan screwed cup) & 18 & 2 \\
Femoral cemented & Poldi (AKV-ultra steel polished stem) & 11 & 7 \\
\multirow{2}{*}{ Femoral non-cemented } & CF30 (CoCrMo sandblasted cemented stem) & 14 & 10 \\
& Walter (hydroxypapatite porous coated stem) & 7 & 0 \\
\hline
\end{tabular}

were placed in capsules containing Tissue Tek (O.C.T. Compound, Sakura, Tokyo, Japan) and frozen in liquid nitrogen. Serial sections (5 $\mathrm{mm}$ thick) were prepared, fixed in ice-cold acetone $(10 \mathrm{~min})$ and left at laboratory temperature for up to $48 \mathrm{~h}$. Before staining the samples were fixed in $4 \%$ paraformaldehyde for $2 \mathrm{~min}$, washed twice in distilled water, and blocked for endogenous peroxidase activity with $0.3 \% \mathrm{H}_{2} \mathrm{O}_{2}$ and $0.1 \% \mathrm{NaN}_{3}$ for $10 \mathrm{~min}$. Sections were washed repeatedly in TBS $(0.05 \mathrm{M}$ TRIS/HCl, $0.15 \mathrm{M} \mathrm{NaCl}, \mathrm{pH}$ 7.6), and non-specific binding was blocked using $5 \%$ fetal calf or goat serum in TBS for $5 \mathrm{~min}$.

Samples were incubated with mouse monoclonal antibodies against RANKL (MAB626, R\&D Systems, Abingdon, UK), CD3, CD45, CD31, CD68 (DakoCytomation, Glostrup, Denmark), CD14 (Biosource, Camarillo, California, USA), and CD55 (BD Pharmingen, San Diego, USA) and with irrelevant control IgG1 (Serotec, Kidlington, Oxford, UK) and IgG2b (Sigma-Aldrich, St. Louis, USA) for $30 \mathrm{~min}$ at $37^{\circ} \mathrm{C}$. After two washes in TBS, secondary staining was performed using a DAKO EnVision+ kit (Dako, Glostrup, Denmark) containing goat anti-mouse immunoglobulin conjugated with dextran polymer and horseradish peroxidase, for $30 \mathrm{~min}$ at laboratory temperature. Immunostaining was developed with 3,3-diaminobenzidine (Sigma) for $5 \mathrm{~min}$ at $37{ }^{\circ} \mathrm{C}$ followed by washing in water.

Preparations were counterstained with Harris hematoxylin, washed, dehydrated in $96 \%$ ethanol, acetone and xylene and mounted with a permanent nonaqueous mounting medium (Solakryl BMX, Penta, ČR).

Positive control tissues (such as those obtained from the osteolytic tissues of patients with RA) and negative control tissues (fibrous tissue interfaces from implants that were not loosened) were also used to verify the specificity of antibody staining.

\section{Results}

Immunohistochemical analysis of the inflammatory tissue from failed total hip joints showed that macrophages were the predominant cell type in regions of extensive osteolysis. The implant-interface tissue also contained fibroblasts, lymphocytes and other inflammatory cells. There were scattered metallic and polyethylene particles both intra- and extracellularly. Occasionally, there were grayish remnants of cemented particles.

Among the total number of 41 loosened acetabular components and 32 loosened femoral components, we did not find significant differences between specimens from acetabular and femoral tissues. From this group of 73 total specimens, 30 were found to contain RANKL-positive cells (Fig. 1).

In terms of patients, we observed RANKLpositive cells in 23 out of our 59 patients: 11 cases with a cemented Poldi acetabular component, 10 cases with a cemented CF30 femoral component, 7 cases with a cemented Poldi femoral component and 2 cases with a non-cemented Walter acetabular component (Table 1).

In our group of tissue specimens, the presence of RANKL-positive cells was found predominantly in tissues with a loosened cemented endoprosthesis. When the relation between the original implantation and the revision was evaluated two groups of patients with RANKL-positive cells were identified. The first group, with a loosened CF30 femoral component, had an average time to revision of 58 months. These tissues were characterized by a large number of polynuclear cells with enormous numbers of metallic particles. The second group comprised patients with loosened cemented Poldi implants, and in two cases with a loosened non-cemented acetabular component, with an average time to revision of 240 months. In contrast to the first group, the dominant finding in this second group of patients was the presence 


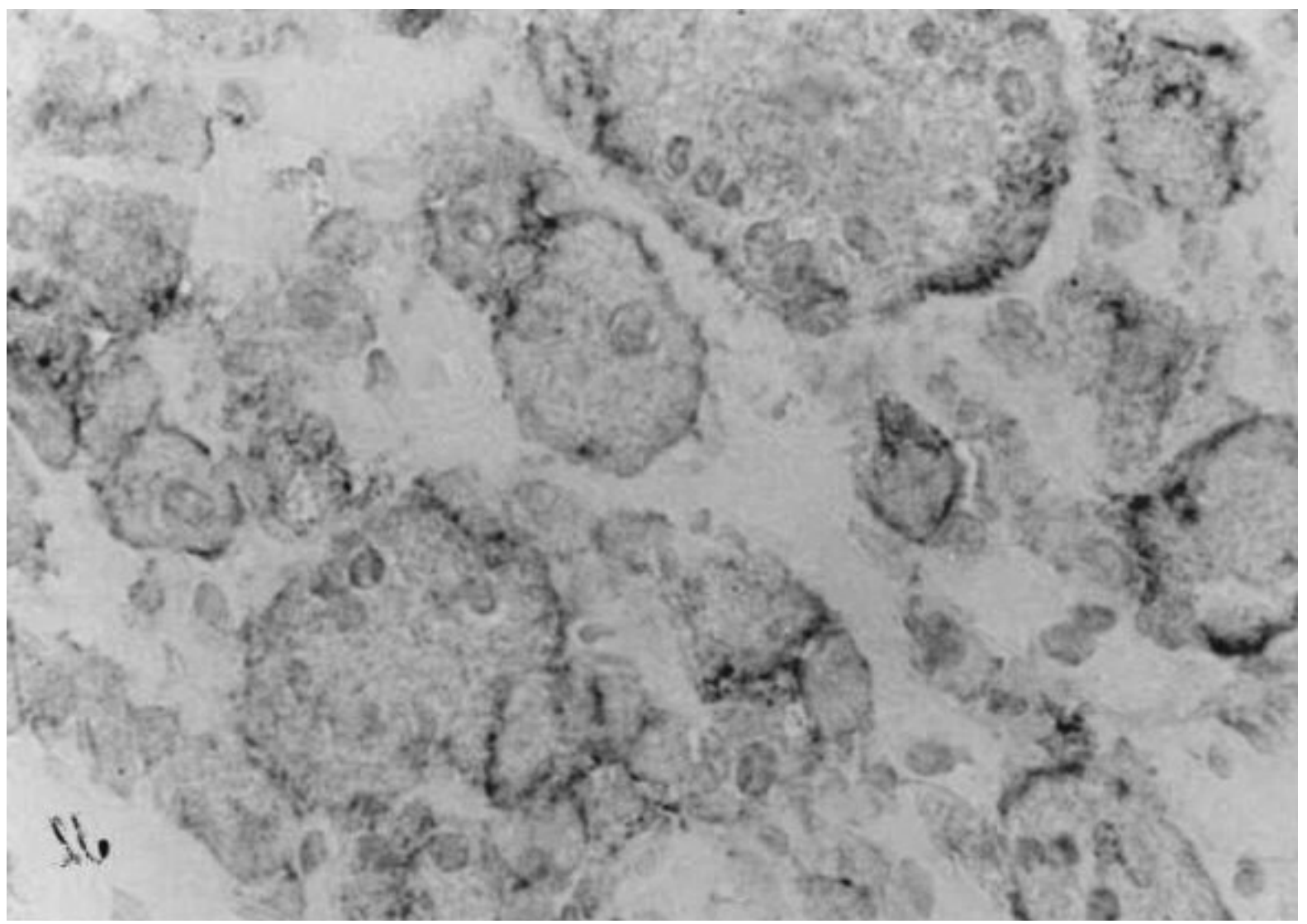

Fig. 1. RANKL-positive multinucleated cells

of polyethylene wear particles.

The radiological presence of osteolysis appeared to correlate with the histological appearance of RANKLpositive samples. All tissues with RANKL-positive cells showed lacunar osteolysis or osteolysis wider than $2 \mathrm{~mm}$ on the x-ray (Table 2).

In the case of non-cemented implants, RANKLpositive cells were present only in two patients with lacunar osteolysis in the area of the acetabulum. Osteolysis wider than $2 \mathrm{~mm}$ in the area of the femoral shaft was not found in cases with loosened femoral components, in which no RANKL-positive cells were found (Table 2).

\section{Discussion}

The ability of macrophages to differentiate into multinucleated cells that exhibit all the phenotypic features of osteoclasts is an important mechanism relevant to their role in implant loosening. Osteoclasts are highly specialized multinucleated cells that are uniquely capable of carrying out lacunar resorption. They are formed by the fusion of bone marrow-derived mononuclear phagocyte precursors that circulate in the monocyte fraction (Fujikawa et al. 1996). Using mouse models of osteoclast formation, it has been shown that monocytes and macrophages, when cocultured with osteoblastic or other bone stromal cells in the presence of 1,25 dihydroxyvitamin $\mathrm{D}_{3}$, can differentiate into mature osteoclasts capable of lacunar bone resorption. Mouse macrophages responding to particles of all implant biomaterials are able to differentiate into osteoclasts (Pandey et al. 1996).

Using a similar in vitro system, investigators found that large numbers of human osteoclasts can be prepared from human blood monocytes and tissue macrophages. Monocytes and tissue macrophages, cocultured with osteoblast-like cells in the presence of human macrophage colony-stimulating factor (M-CSF), form numerous multinucleated cells that express all the cytological and functional phenotypic characteristics of osteoclasts. These cells are positive for tartrate-resistant acid phosphatase, express receptors for calcitonin and vitronectin, and possess the ability to carry out lacunar bone resorption. Because tissue macrophages are derived from monocytes, and monocyte migration is stimulated by the presence of particles, it was not surprising to find that inflammatory foreign body macrophages isolated 
Table 2. The occurrence of RANKL-positive cells according to the radiological presence of osteolysis: a comparison of cemented and non-cemented implants.

\begin{tabular}{lcccc}
\hline $\begin{array}{l}\text { Type of } \\
\text { osteolysis }\end{array}$ & Lacunar & $\begin{array}{c}\text { Wider } \\
\text { than }\end{array}$ & $\begin{array}{c}1-2 \\
\text { mm }\end{array}$ & $\begin{array}{c}\text { 0-1 } \\
\text { mm }\end{array}$ \\
& & $2 \mathrm{~mm}$ & & \\
\hline
\end{tabular}

\begin{tabular}{|c|c|c|c|c|}
\hline \multicolumn{5}{|c|}{ Cemented implants } \\
\hline $\begin{array}{l}\text { Number of } \\
\text { samples }\end{array}$ & 25 & 52 & 68 & 61 \\
\hline $\begin{array}{l}\text { RANKL positive } \\
\text { samples }\end{array}$ & 22 & 5 & 1 & 0 \\
\hline $\begin{array}{l}\% \text { of } R A N K L \\
\text { positive samples }\end{array}$ & $88 \%$ & $10 \%$ & $1 \%$ & $0 \%$ \\
\hline \multicolumn{5}{|c|}{ Non-cemented implants } \\
\hline $\begin{array}{l}\text { Number of } \\
\text { samples }\end{array}$ & 4 & 15 & 53 & 31 \\
\hline $\begin{array}{l}\text { RANKL positive } \\
\text { samples }\end{array}$ & 2 & 0 & 0 & 0 \\
\hline $\begin{array}{l}\% \text { of RANKL } \\
\text { positive samples }\end{array}$ & $50 \%$ & $0 \%$ & $0 \%$ & $0 \%$ \\
\hline
\end{tabular}

directly from the pseudomembrane and pseudocapsule around loosened arthroplasty components are capable of osteoclast differentiation (Sabokbar et al. 1997). In contrast to osteoclast formation from monocytes and macrophages derived from other tissues, the addition of M-CSF was found not to be essential for osteoclast differentiation from arthroplasty-derived macrophages. This appears to be caused by sufficient local M-CSF production in periprosthetic tissues. This aspect also correlates with the finding of abundant M-CSF in the synovial fluid of prosthetic joints (Takei et al. 2000).

RANKL expression by osteoblasts/bone marrow stromal cells and the presence of M-CSF are two main factors required for osteoclast differentiation. A decoy receptor for RANKL - osteoprotegerin (OPG), a member of the TNF receptor superfamily - inhibits osteoclast formation and bone resorption. Human arthroplastyderived macrophages have been shown to be capable of osteoclast formation in the presence of soluble RANKL alone; this process is inhibited by the addition of OPG (Itonaga et al. 2000). Other authors (Haynes et al. 1993) demonstrated that metallic and polymeric particles stimulate the expression of RANKL and M-CSF as well as other humoral factors that influence osteoclast formation. These particles also stimulate the expression of osteoprotegerin.

A number of cellular and humoral factors are known to influence RANKL and OPG expression. Osteoclast formation in periprosthetic tissues can be viewed as an imbalance in the production of these two factors. Various cytokines and growth factors (apart from M-CSF) abundant in periprosthetic tissues in cases of aseptic loosening, such as IL-1 and TNF-alpha, increase OPG mRNA expression in osteoblasts, suggesting that these factors that stimulate osteoclastic bone-resorbing activity appear to act conversely to downregulate osteoclast formation (Hofbauer et al. 2000, Mandelin et al. 2003). Prostaglandins such as $\mathrm{PGE}_{2}$ have also been shown to increase RANKL production and to decrease OPG release, thus stimulating osteoclast formation and bone resorption. Inflammatory cells, such as T-cells, are present in the arthroplasty membrane and may influence osteoclast differentiation and periprosthetic osteolysis by modulating RANKL expression and OPG production. Recent studies also highlighted the role of some cytokines (TNF-alpha, TGF-beta and IL-1) in the induction of osteoblast formation, both in the presence and absence of RANKL (but not M-CSF) (Epstein et al. 2005).

In spite of the fact that there have been many reports of a causal relationship between endoprosthesis loosening and the RANKL/OPG system, most of these have been in vitro studies, the majority of which evaluated small groups consisting of 5 to 10 patients (Haynes et al. 2001, Clohisy et al. 2003, Horiki et al. 2004, Baumann et al. 2004, Masui et al. 2005). These studies mainly demonstrate the crossover of macrophage and osteoclast functions. The investigators have shown that osteoclasts are capable of phagocytosing wear particles and that this function does not abrogate specific osteoclast properties.

In our group of patients, RANKL-positive cells were found only in half of the loosened hip endoprostheses, particularly in the cases with cemented implants. A remarkable finding was the presence of RANKL-positive cells in the cases with lacunar periprosthetic osteolysis. Furthermore, the prominent presence of RANKL-positive cells in groups of patients with large numbers of wear particles in their tissue (the first group, with cemented implants and over 12 years from the original surgery, and the second group, with a large number of metallic wear particles in the periprosthetic tissue) agrees with the hypothesis that chronic stimulation of macrophages by particulate debris results in osteoclastic bone resorption. On the other hand, the absence of RANKL-positive cells, along with 
minimal osteolytic changes of the periprosthetic bone, is indicative of another mechanism of osteolysis initiation. The onset of bone resorption may occur at totally different rates among patients with the same type of implant. Variability in the patient response to wear debris likely reflects a multifactorial process, which can include factors of genetically based cellular reactivity.

In the context of the various local factors possibly influencing the regulation of bone metabolism around a joint endoprosthesis, it is necessary to speculate about the role of adipocytokines, specifically about leptin and resistin. While leptin appears to be a factor regulating bone formation and the activity of osteoclasts, resistin can act as a local factor influencing inflammation. Understanding the role of these factors in the process of joint arthroplasty loosening is the goal of current studies.

\section{Conclusion}

We have demonstrated the presence of the osteoclastogenic molecule RANKL in the periprosthetic tissues around loosened total joint endoprostheses. We have shown that RANKL is present only in tissues with a large amount of wear debris and predominantly in cases involving loosened cemented implants. Our results also raise the question of whether the RANKL/OPG system is important for all types of joint implant loosening or if there are other mechanisms underlying the initiation of prosthetic loosening.

Although it is generally understood that the loss of total joint implant fixation occurs secondary to the bone loss induced by wear debris, no consistent therapeutic approach is available to prevent these consequences for the patient. An understanding of the role of the key osteoclastogenic factors in periprosthetic bone loss may help to identify targets for future therapeutic approaches.

\section{Acknowledgements}

MZO 00023728.

\section{References}

BAUMANN B, RADER CP, SEUFERT J, NOTH U, ROLF O, EULERT J, JAKOB F: Effects of polyethylene and TiAlV wear particles on expression of RANK, RANKL and OPG mRNA. Acta Orthop Scand 75: 295-302, 2004.

CHUN L, YOON J, SONG Y, HUIE P, REGULA D, GOODMAN S: The characterization of macrophages and osteoclasts in tissues harvested from revised total hip prostheses. J Biomed Mater Res 48: 899-903, 1999.

CLOHISY JC, FRAZIER E, HIRAYAMA T, ABU-AMER Y: RANKL is essential cytokine mediator of polymethylmethacrylate particle-induced osteoclastogenesis. J Orthop Res 21: 202-212, 2003.

EPSTEIN NJ, WARME BA, SPANOGLE J, MA T, BRAGG B, SMITH RL, GOODMAN SB: Interleukin-1 modulates periprosthetic tissue formation in an intramedullary model of particle-induced inflammation. J Orthop Res 23: 501-510, 2005.

FUJIKAWA Y, QUINN J, SABOKBAR A, MCGEE JO'D, ATHANASOU NA: The human mononuclear osteoclast precursor circulates in the monocyte fraction. Endocrinology 139: 4058-4060, 1996.

HALUZÍK M, FIEDLER J, NEDVÍDKOVÁ J, ČEŠKA R: Serum leptin concentrations in patients with combined hyperlipidemia: relationship to serum lipids and lipoproteins. Physiol Res 48: 363-368, 1999.

HALUZÍK M, MATOULEK M, SVAČINA S, HILGERTOVÁ J, HAAS T: The influence of short-term fasting on serum leptin levels, and selected hormonal and metabolic parameters in morbidly obese and lean females. Endocr Res 27: 251-260, 2001.

HAYNES DR, ROGERS SD, HAY S, PEARCY MJ, HOWIE DW: The differences in toxicity and release of bone resorbing mediators induced by titanium and cobal-chromium-alloy wear particles. J Bone Joint Surg Am 75: 825-833, 1993.

HAYNES DR, CROTTI TN, POTTER AE, LORIC M, ATKINS GJ, HOWIE DW, FINDLAY DM: The osteoclastogenesis molecules RANKL and RANK are associated with periprosthetic osteolysis. J Bone Joint Surg Br 83: 902-911, 2001.

HOFBAUER LC, KHOSLA S, DUNSTAN CR, LACEY DL, BOYLE WJ, RIGGS BL: The roles of osteoprotegerin and osteoprotegerin ligand in the paracrine regulation of bone resorption. J Bone Miner Res 15: 2-12, 2000. 
HORIKI M, NAKASE T, MYOUI A, SUGANO N, NISHII T, TOMITA T, MIYAJI T, YOSHIKAWA H: Localisation of RANKL in osteolytic tissue around a loosened joint prosthesis. $J$ Bone Miner Metab 22: 346-351, 2004.

ITONAGA I, FUJIKAWA Y, SABOKBAR A, ATHANASOU NA: The effect of osteoprotegerin and osteoprotegerin ligand on human arthroplasty macrophage-osteoclast differentiation. Ann Rheum Dis 59: 26-31, 2000.

JAHODA D, VAVŘÍK P, LANDOR I, POKORNÝ D: The approaches to infection of knee prostheses joint in patients with rheumatoid arthritis. (in Czech) Čes Revmatol 8: 83-90, 2000.

JAHODA D, SOSNA A, LANDOR I, VAVŘÍK P, POKORNÝ D: Canalized spacer in the treatment of deep infection of the total hip arthroplasty using a two-stage reimplantation. Operative Orthopaedie Traumatologie 15: 57-69, 2003a.

JAHODA D, SOSNA A, LANDOR I, VAVŘíK P, POKORNÝ D, HUDEC T: Two-stage reimplantation using spacersthe method of choice in treatment of hip joint prosthesis-related infections. Comparison with methods used from 1979 to 1998. (in Czech) Acta Chir Orthop Traumatol Cech 70: 17-24, 2003b.

JAHODA D, SOSNA A, LANDOR I, VAVŘÍK P, POKORNÝ D: A cannulated articulating spacer - a functional implant for treatment of infected hip joint prostheses. (in Czech) Acta Chir Orthop Traumatol Cech 71: 73-79, 2004.

KŘÍŽOVÁ J, SULKOVÁ S, BEDNÁŘOVÁ V, PAŘíZKOVÁ J, KOTRLÍKOVÁ E, HALUZÍK M: Soluble leptin receptor levels in patients with chronic renal failure. Physiol Res 52: 347-351, 2003.

LACEY DL, TIMMS E, TAN HL, KELLEY MJ, DUNSTAN CR, BURGESS T, ELLIOTT R, COLOMBERO A, ELLIOTT G, SCULLY S, HSU H, SULLIVAN J, HAWKINS N, DAVY E, CAPPARELLI C, ELI A, QIAN YX, KAUFMAN S, SAROSI I, SHALHOUB V, SENALDI G, GUO J, DELANEY J, BOYLE WJ: Osteoprotegerin ligand is a cytokine that regulates osteoclast differentiation and activation. Cell 93: 165-176, 1998.

LANDOR I, VAVŘÍK P, HAVELKA S, JAHODA D: Factors affecting the development of para-articular ossification in total hip replacement. (in Czech) Acta Chir Orthop Traumatol Cech 60: 76-80, 1993.

LANDOR I, SOSNA A, FRIČ V, JAHODA D: First pilot results with non-cemented total substitution of the hip joint. (in Czech) Acta Chir Orthop Traumatol Cech 61: 132-137, 1994.

LANDOR I, SOSNA A, VAVŘÍK P, POVÝŠIL C, JAHODA D: Clinical study of the effect of hydroxyapatite on the osteointegration by total hip replacement. Chir Organi Mov 82: 381-392, 1997.

LANDOR I, VAVŘÍK P, JAHODA D: General principles of infection treatment in joint replacements. (in Czech) Acta Chir Orthop Traumatol Cech 72: 183-190, 2005.

MANDELIN J, LI TF, LILJESTROM M, KROON ME, HANEMAAIJER R, SANTAVIRTA S, KONTTINEN YT: Imbalance of RANKL/RANK/OPG system in interface tissue in loosening of total hip replacement. $J$ Bone Joint Surg Br 85: 1196-1201, 2003.

MASUI T, SAKANO S, HASEGAWA Y, WARASHINA H, ISHIGURO N: Expression of inflammatory cytokines, RANKL and OPG induced by titanium, cobalt-chromium and polyethylene particles. Biomaterials 26: 16951702, 2005.

MARUNA P, GURLICH R, FRAŠKO R, HALUZÍK M: Serum leptin levels in septic men correlate well with C-reactive protein (CRP) and TNF-alpha but not with BMI. Physiol Res 50: 589-594, 2001.

PANDEY R, QUINN J, JOYNER C, TRIFFITT JT, ATHANASOU NA: Arthroplasty implant biomaterial particleassociated macrophages differentiate into osteoclastic bone-resorbing cells. Ann Rheum Dis 55: 388-395, 1996.

SABOKBAR AS, FUJIKAWA Y, NEALE S, MURRAY D, ATHANASOU NA: Human arthroplasty derived macrophages differentiate into osteoclastic bone-resorbing cells. Ann Rheum Dis 56: 414-420, 1997.

SCHMALZRIED TP, JASTY M, HARRIS WH: Periprosthetic bone loss in total hip arthroplasty. Polyethylene wear debris and the concept of the effective joint space. J Bone Joint Surg Am 74: 849-863, 1992.

SOSNA A, BEZNOSKA J, JAHODA D, LANDOR I: Non-cemented ceramic acetabular component. Acta Chir Orthop Traumatol Cech 63: 189-195, 1996 (in Czech).

ŠLOUF M, ŠLOUFOVÁ I, HORÁK Z, ŠTĚPÁNEK P, ENTLICHER G, KREJČÍK M, RADONSKÝ T, POKORNÝ D, SOSNA A: New fast method for determination of number of UHMWPE wear particles. J Mater Sci Mater Med 15: 1-12, 2004. 
TAKEI I, TAKAGI M, IDA H, OGINO T, SANTAVIRTA S, KONTINNEN YT: High macrophage-colony stimulating factor levels in synovial fluid of loose artificial hip joints. J Rheumatol 27: 894-899, 2000.

VAVŘ́K P LANDOR I, JAHODA D: The results of treating the alloplastic knee joint. Acta Chir Orthop Traumatol Cech 67: 121-127, 2000 (in Czech).

VON KNOCH M, JEWISON DE, SIBONGA JD, SPRECHER C, MORREY BF, LOER F, BERRY DJ, SCULLY SP: The effectiveness of polyethylene versus titanium particles in inducing osteolysis in vivo. $J$ Orthop Res 22: 237-243, 2004.

YASUDA H, SHIMA N, NAKAGAWA N, YAMAGUCHI K, KINOSAKI M, MOCHIZUKI S, TOMOYASU A, YANO K, GOTO M, MURAKAMI A, TSUDA E, MORINAGA T, HIGASHIO K, UDAGAWA N, TAKAHASHI N, SUDA T: Osteoclast differentiation factor is a ligand for osteoprotegerin/osteoclastogenesis inhibitory factor and is identical to TRANCE/RANKL. Proc Natl Acad Sci USA 95: 3597-3602, 1998.

\section{Corresponding author}

D. Veigl, Leopoldova 902/15, 14900 Praha 4, Czech Republic. E-mail: veigl@iol.cz 